\title{
Caracterização e cultivo de uma espécie de cogumelo silvestre isolado no Brasil
}

\author{
Characterization and cultivation of a \\ wild mushroom species isolated in Brazil
}

\author{
Cristina Sayuri Maki ${ }^{1}$; Luzia Doretto Paccola-Meirelles²
}

\section{Resumo}

\begin{abstract}
Visando a busca e a domesticação de basidiomicetos ainda inexplorados, coletou-se cogumelos silvestres em regiões de pastagens e próximos a esterco de gado no município de Tamarana, PR. Um basidiomiceto comestível da ordem Agaricales foi classificado como pertencente à espécie Macrolepiota bonaerensis (=Lepiota procera, forma bonaerensis (Speg.) Rick ou M. procera (Scop.:Fr.) Sing.). O micélio foi isolado e caracterizado em relação à taxa de crescimento em diferentes meios de cultura. Observou-se um crescimento vigoroso em meio BDA $\left(\mathrm{pH} 5, \pm 25^{\circ} \mathrm{C}\right)$. $\mathrm{O}$ meio de aveia foi o mais adequado para cultivo submerso. O micélio de $M$. bonaerensis secreta enzimas dos tipos lipase, celulase e protease, e as análises citológicas confirmaram a condição binucleada do micélio, a presença de septos e de grampos de conexão nas hifas. A frutificação dos cogumelos ocorreu no substrato constituído de húmus + terra (1:9) esterilizados, acrescido de terra de cobertura e carvão ativado.
\end{abstract}

Palavras-chave:

\begin{abstract}
Wild mushrooms were collected close to cattle manure in pasture areas in Tamarana (Paraná/Brazil), with the objective of finding and domesticating new non-exploited basidiomycetes. An edible basidiomycete of the Agaricales order was classified as belonging to the Macrolepiota bonaerensis species (=Lepiota procera, form bonaerensis (Speg.) Rick or M. procera (Scop.:Fr) Sing.). The mycelia was isolated and characterized for growth rate in different culture media. A vigorous growth was observed in PDA Medium ( $\mathrm{pH} 5, \pm 25^{\circ} \mathrm{C}$ ). The oat culture medium was the most appropriate for cultivation submersed. $M$. bonaerensis mycelia secretes lipase, cellulase and protease exoenzyme types. Cytological analyses confirmed the bi-nucleated condition of the mycelia, the presence of septa and clamp connections in the hypha. The fructification occurred in the substrate composed of sterilized humus + soil (1:9) plus casing layer with active carbon.
\end{abstract}

Key words:

\footnotetext{
1 Doutoranda em Genética e Melhoramento de Plantas pela Escola Superior de Agricultura "Luiz de Queiroz"/USP. E-mail: csmaki@esalq.usp.br

2 Professor Associado da Universidade Estadual de Londrina- Departamento de Biologia Geral.
} 
Maki, C. S. et al.

\section{Introduction}

Man has been consuming mushrooms as part of the normal diet for many years. Recently, consumption has increased because of production expansion and of diversification in the cultivated species. A gradual increase in the popularity of mushrooms has been observed in many countries, where they are considered a refined culinary option and a healthy source that enrich the human diet.

Mushrooms may be produced in organic substrates from agricultural crop remains, pulp and straw. Furthermore, because of its ability to degrade plant polymers, such as lignin, hemicellulose and cellulose, mushrooms can be used in animal meal production by bioconversion processes of lignocellulolitic residues from agroindustry (MILES and CHANG, 1997).

Edible mushrooms, although rich in proteins and low in calories, are little used in Brazilian cooking, when compared to European and Asian countries. Today, about 2,000 species of edible mushrooms are known, but a few are cultivated and comercialized in the world. The search and domestication of Brazilian edible mushrooms have great potential, especially when the great diversity of species which have not even been cataloged is considered. The domestication of these species will allow their production and commercial exploitation and the country will have another national product adapted to our climate and environment competing in the external market.

This study describes the isolation, identification, characterization and conditions for fructification of an edible mushroom (Macrolepiota bonaerensis) that develops naturally in pastures in the northern region of the state of Paraná, Brazil.

\section{Materials and Methods}

\section{Mycelia Isolation}

Basidiocarps were collected, disinfected with a $2 \%$ sodium hypochloride solution and washed with distilled sterilized water under aseptic conditions. The mycelia was isolated and kept at $25^{\circ} \mathrm{C}$ in PDA culture medium (Potato Dextrose Agar - Biobrás) for approximately 12 days. After this period, the plates containing mycelia were stored at $4^{\circ} \mathrm{C}$.

\section{Assessment of mycelial development}

The mycelial growth was assessed by radial growth and mycelial mass. Four culture media were used: Saboraud, Potato medium, Oatmeal medium (w/v: 5\% oat flakes + distilled water), Pontecorvo's Minimum medium and Pontecorvo's Complete medium (PONTECORVO et al., 1953). Agar was added to the solid medium at the $1.5 \%(\mathrm{w} / \mathrm{v})$.

The radial mycelia growth in solid culture medium was assessed at the $3^{\text {rd }}, 6^{\text {th }}$ and $9^{\text {th }}$ day of incubation. The mycelial mass was assessed in cultures grown in $50 \mathrm{~mL}$ of liquid medium for 42 days. Three culture temperatures $\left(25^{\circ}, 28^{\circ}\right.$ and $\left.37^{\circ} \mathrm{C}\right)$ and five $\mathrm{pHs}(5,6$, 7,8 , and 9) were evaluated to optimize the abiotic conditions for the fungus mycelial development. The mycelia was collected, filtered with a vacuum pump, washed three times in sterilized distilled water, weighed to obtain the fresh weight and then, dehydrated in a stove at $50^{\circ} \mathrm{C}$ to obtain the dry weight.

\section{Cytological Analyses}

The cytological analyses were carried out in Potato Dextrose Agar (PDA). Sterilized dialysis membranes $(1 \times 2 \mathrm{~cm})$ were placed on the medium surface and a mycelium disc ( $10 \mathrm{~mm}$ diameter) was placed on the dialysis membranes. The plates were incubated at $25^{\circ} \mathrm{C}$ for three days. The mycelium discs were then removed and the membranes stained with giemsa as described by Tanaka et al. (1979).

\section{Exoenzyme Production}

The production of exoenzymes was assessed in specific culture medium to detect degradation of starch, lipids, cellulose and proteins, following the technique 
described by Hankin and Anagnostakis (1975). A 10 mm mycelium disc was placed on each plate containing specific medium. The enzymatic degradation halo and the mycelial growth diameter were measured to calculate the enzymatic activity index:

$\mathrm{EAI}=\mathrm{EDH} / \mathrm{MGD}$, where,

$\mathrm{EAI}=$ enzymatic activity index

$\mathrm{EDH}=$ enzymatic degradation halo

MGD = mycelial growth diameter

Amylase. The amylase activity was analyzed by culturing M. bonaerensis mycelium in Pontecorvo's Minimum medium substituting the glucose for soluble starch, in the same proportion. After a seven-day incubation at $25^{\circ} \mathrm{C}$, a $0.25 \%$ lugol solution was added to the plate in order to observe the enzymatic degradation halo.

Lipase. The fungus was cultured in specific medium (w/v: $1 \%$ peptone $+0.5 \% \mathrm{NaCl}+0.01 \%$ $\mathrm{CaCl}_{2} .2 \mathrm{H}_{2} \mathrm{O}+1.5 \%$ agar $+1 \%$ Tween $20+$ distilled water) at $25^{\circ} \mathrm{C}$, for seven days. After growth, the plates were submitted to $4^{\circ} \mathrm{C}$ for two hours and the lipolitic degradation halo was observed.

Protease. A solution of $8 \%$ gelatin was added to Pontecorvo's Minimum medium to detect the proteolitic activity of the fungus. After growth at $25^{\circ} \mathrm{C}$ for seven days, $20 \mathrm{~mL}$ of a saturated ammonia sulfate solution was added to the plates, and the proteolitic degradation halo was observed.

Cellulase. The substrate used to detect cellulase activity of the fungus was carboxy-methyl-cellulose. The glucose in the Pontecorvo's Minimum medium was substituted for carboxy-methyl-cellulose, in the same proportion. After growth at $25^{\circ} \mathrm{C}$ for seven days, the culture was covered with $0.1 \%$ congo-red stain for 15 minutes. The stain was discarded, and a $\mathrm{NaCl}(1 \mathrm{~N})$ solution was added to the plates. A cellulolitic degradation halo was observed.

\section{Selection of the Fructification Substrate}

The following substrates were used for mushroom fructification: 1) humus, 2) humus + soil (1:9), 3) humus + cattle manure, 4) cattle manure + soil and 5) cattle manure (COCHRANE, 1958). The experiment was initially carried out on Petri dishes to assess the mycelium radial growth. The plates containing $100 \mathrm{~g}$ of substrate were sterilized in autoclave for $90 \mathrm{~min}$ at $120^{\circ} \mathrm{C}$. A $10 \mathrm{~mm}$ diameter mycelium disc was placed in the center of each plate and the diameter of the colonies was measured after seven days of growth at $25^{\circ} \mathrm{C}$.

For the fructification process, $2 \mathrm{Kg}$ of substrates, humus and humus + soil, were placed in polypropylene bags and sterilized for $90 \mathrm{~min}$ in autoclave at $120^{\circ} \mathrm{C}$. The bags were incubated at $25^{\circ} \mathrm{C}$ for the mycelium running. After 60 days, the bags were partially opened and $50 \%$ of the treatments received cover soil (soil taken from deep layers), with or without active carbon ( $1 \mathrm{~g} / 5 \mathrm{~kg}$ compost), on the surface.

\section{Results and Discussion}

\section{Fungus Identification}

The fungus isolated in Tamarana (Paraná/Brazil) was identified as belonging to the Basidiomycete Class, Agaricales Order, Macrolepiota bonaerensis species. It is an edible species, described in 1946, and is also known as Lepiota procera form bonaerensis (Speg.) Rick or Macrolepiota procera (Scop.:Fr) Sing. It is a soil mushroom, with a rigid hollow stalk and a fleshy, ovoid at first, $10-25 \mathrm{~cm}$ diameter basidiocarp that expands to a parasol shape. The basidiocarp is pale buff with brown shades, with soft brown scales on the upper surface and parallel gills in the lower surface. The stem is tall, up to 35 $\mathrm{cm}$ long, slender with a bulbous base with a brown snake-like pattern and moveable double wooly ring. The gills are free, soft and whitish and the spores are colorless and white. This mushroom was described as belonging to one of the best edible 
Maki, C. S. et al.

species that is common throughout Europe and widely distributed in the Northern Hemisphere and some authors described it as one of the favorites among experienced mushroom hunters (LINCOFF, 1995; SPOONER, 1966).

\section{Mycelial Development}

The nutritional requirements of this mushroom are relatively simple. PDA was the most efficient culture medium for radial growth, followed by the Complete culture medium (Table 1). The Minimum and Oat culture medium, which were not statistically different, were the least efficient solid media for $M$. bonaerensis mycelial development. On the other hand, Oatmeal medium was the best in submersed culture (Figure 1), followed by Potato broth and Saboraud, which were not statistically different. The Minimum and Complete culture medium were the least efficient for submersed culture of $M$. bonaerensis. The best temperature for mycelial growth was $25^{\circ} \mathrm{C}$ (Figure 2) although the fungus mycelium can develop at higher temperatures. There were significant differences in growth among the three analyzed temperatures. Although at reduced rate, mycelial growth continued at $37^{\circ} \mathrm{C}$ reinforcing the potential of $M$. bonaerensis as a species for cultivation in tropical climate regions, such as Brazil. M. bonaerensis growth was not affected by hydrogen ion concentration, as the mycelia developed adequately within the assessed $\mathrm{pH}$ values, and no studied $\mathrm{pH}$ value restricted growth (Figure 3 ). This suggests that $M$. bonaerensis was able to change the $\mathrm{pH}$ of the medium (COCHRANE, 1958) as observed for Lentinula edodes (PRZYBYLOWICZ and DONOGHUE, 1990). These changes in $\mathrm{pH}$ during the development of some fungi are related to fructification induction (JABLONSKY, 1981; KALBERER, 1995).
Table 1 - Radial growth (cm) of M. bonaerensis mycelium inoculated in different culture media and cultivated at $25^{\circ} \mathrm{C}$ for 3,6 and 9 days. The treatments were significantly different by the Tukey test at $5 \%$ probability. Means followed by the same letter in the line did not differ statistically.

\begin{tabular}{lccccc}
\hline & PDA & SABORAUD & MINIMUM & COMPLETE & OAT \\
\hline 3 DAYS & $1.8^{\mathrm{b}}$ & $1.7^{\mathrm{b}}$ & $1.3^{\mathrm{b}}$ & $3.5^{\mathrm{a}}$ & $1.2^{\mathrm{b}}$ \\
6 DAYS & $5.9^{\mathrm{a}}$ & $3.9^{\mathrm{c}}$ & $2.5^{\mathrm{d}}$ & $4.4^{\mathrm{b}}$ & $2.5^{\mathrm{d}}$ \\
9 DAYS & $6.9^{\mathrm{a}}$ & $4.9^{\mathrm{c}}$ & $3.3^{\mathrm{d}}$ & $5.5^{\mathrm{b}}$ & $3.4^{\mathrm{d}}$ \\
\hline
\end{tabular}

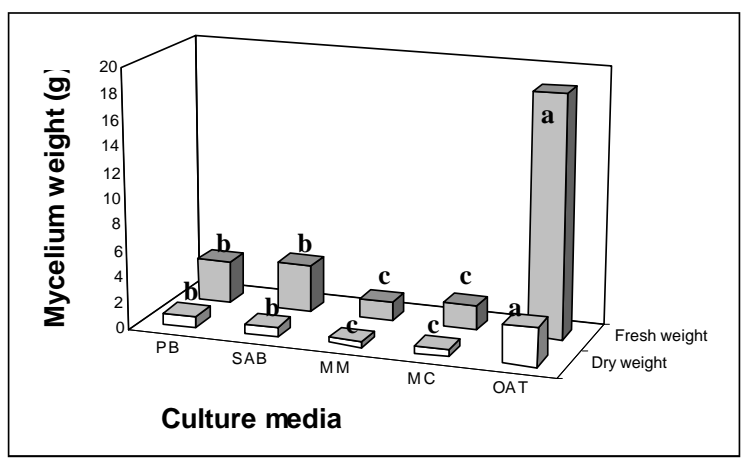

Figure 1 - Dry and fresh weight of $M$. bonaerensis mycelium cultivated on different culture media at $25^{\circ} \mathrm{C}$ for 42 days (submmersed culture). $\mathrm{PB}=$ Potato Broth; $\mathrm{SAB}=$ Saboraud; $\mathrm{MM}=$ Minimum medium $; \mathrm{MC}=$ Complete medium; OAT= Oat meal.

Means followed by the same letter did not differ statistically by the Tukey test $(\mathrm{p} \leq 0,05)$.

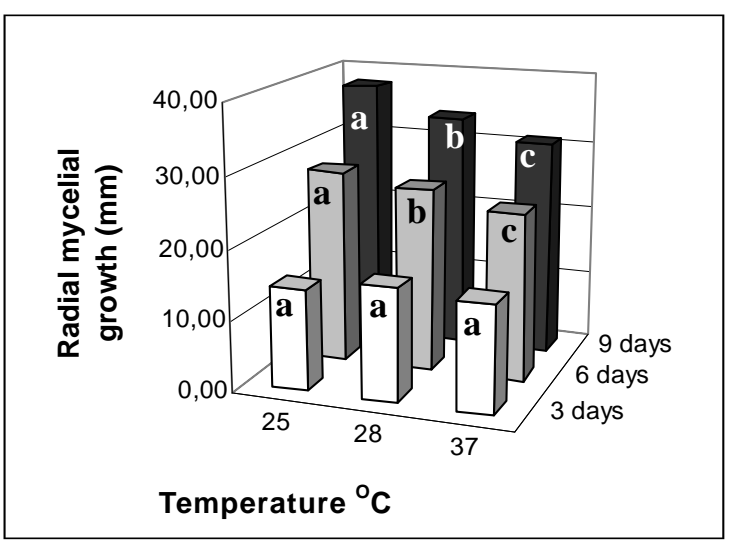

Figure 2 - Radial growth of $M$. bonaerensis mycelium inoculated at different temperatures $\left(25,28\right.$ and $\left.37^{\circ} \mathrm{C}\right)$ and cultivated in PDA medium for 3, 6 and 9 days. 5\% probability. Means followed by the same letter, in the line, did not differ statistically by Tukey test $(\mathrm{p} \leq 0,05)$ 


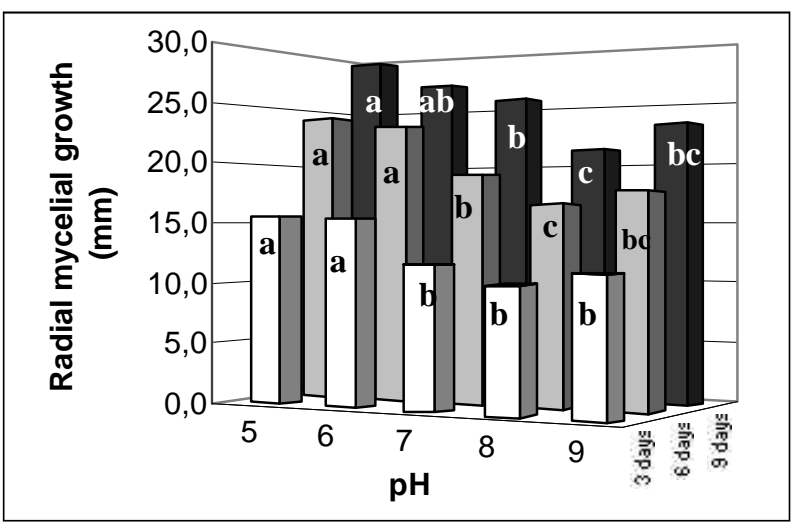

Figure 3 - Radial growth of the $M$. bonaerensis inoculated in PDA medium with different $\mathrm{pH}(5,6,7,8$, and 9) and cultivated for 3,6, and 9 days. Means followed by the same letter did not differ statistically by the Tukey test $(\mathrm{p} \leq 0,05)$

\section{M. bonaerensis Exoenzymatic Activity}

Figure 4 shows the exoenzymatic activities of amylase, lipase, cellulase and protease, by $M$. bonaerensis mycelia. These activities were measured by presence of the degradation halos. The absence of the degradation halo for amylase activity suggests that $M$. bonaerensis degrades simple carbon sources more readily (e.g. glucose), and secretes enough amylases only to break the starch for mycelial growth and this quantity was not detectable by the test which was made. On the other hand, lipid, protein and cellulose degradation halos were very evident, suggesting that degradation of organic compounds by $M$. bonaerensis mycelia occur during its vegetative development.

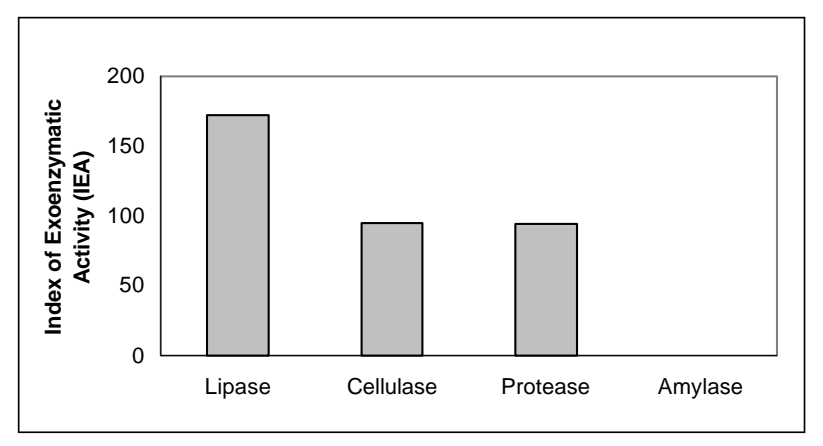

Figure $4-M$. bonaerensis exoenzymatic activity

\section{Cytological Analysis}

$M$. bonaerensis hyphae show one or two nuclei per cell, are septate with communicating cell compartments. A considerable number of clamp connections, structures that are associated with the maintenance of the dikaryotic nature of the mycelia, was also observed.

\section{Spawn Running and Mushroom Development}

Substrates containing humus were adequate for $M$. bonaerensis mycelial growth on Petri dishes (Figure 5). Substrates containing humus + soil mixture (COCHRANE, 1958) were best for growth, followed by those with only humus and humus + manure. However, substrates containing manure did not allow satisfactory mycelial development, except when complemented by humus. Fructification only occurred in the humus + soil treatment complemented with casing layer plus active carbon (Table 2). No fructification was observed in the other treatments.

An average of $58 \mathrm{~g} / 2 \mathrm{~K}$ of substrate of mushroom morphologically similar to those isolated in the pastures, was harvested. The mushroom was approximately $25 \mathrm{~cm}$ high, with a large and creamcolored with brown scales basidiocarp and a rigid stalk. Although big, the mushroom is quite delicate and fragile. The substrate colonization occurred in all the treatments, but colonization followed by fructification only occurred in the bags with gas exchange. No mycelial growth was observed in any completely sealed bag.

This mushroom species is aerobic and oxygen and carbon dioxide are atmosphere gas components of great importance in its biology (MILES and CHANG, 1997). Although fructification was considered low, this study reports the first production process under controlled conditions of $M$. bonaerensis isolated in Brazil. The fructification process can be improved, and this basidiomycete will then integrate the list of cultivated edible mushrooms. 
Maki, C. S. et al.

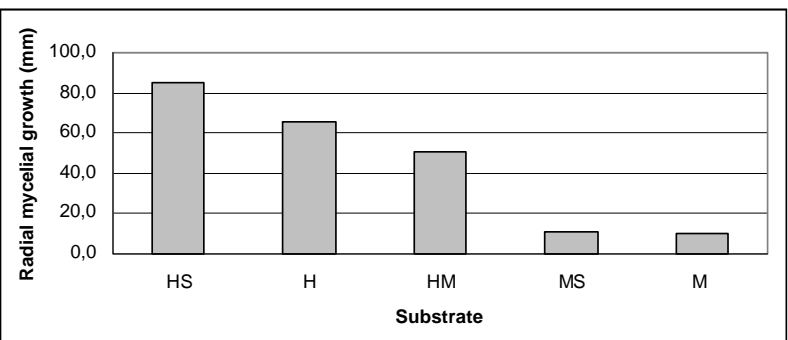

Figure 5 - Radial growth of mycelium of $M$. bonaerensis inoculated in different types of compost and incubated at $25^{\circ} \mathrm{C}$ for aproximately 8 days. Legend: HS (Humus + soil 1:9), H (humus), HM (humus + cattle manure 1:9), MS (cattle manure + soil 1:1), and M (cattle manure).

Table 2 - Growth and fructification of $M$. bonaerensis on different substrates.

\begin{tabular}{|c|c|c|c|c|c|c|c|c|c|c|}
\hline \multirow[b]{2}{*}{ Treatments } & \multicolumn{5}{|c|}{ Mycelial Grown } & \multicolumn{5}{|c|}{ Frutification ${ }^{* *}$} \\
\hline & HS & $\mathbf{H}$ & HM & MS & M & HS & $\mathbf{H}$ & HM & MS & M \\
\hline Completely sealed bags & - & - & - & - & - & - & - & - & - & - \\
\hline $\begin{array}{l}\text { Bags with gas exchange } \\
\text { without soil casing layer }\end{array}$ & + & + & + & + & + & - & - & - & - & - \\
\hline $\begin{array}{l}\text { Bags with gas exchange } \\
\text { with soil casing layer }\end{array}$ & + & + & + & + & + & - & - & - & - & - \\
\hline $\begin{array}{l}\text { Bags with gas exchange } \\
\text { with soil casing layer } \\
\text { plus active carbon }\end{array}$ & + & + & + & + & + & + & - & - & - & - \\
\hline
\end{tabular}

${ }^{*}$ To see legend of the Figure 5

$+*$ frutification

$-=\tilde{n}$ frutification

\section{Aknowledgments}

The authors thank the team led by Dr. Maria Auxiliadora Cavalcanti of the Universidade Federal de Pernambuco (Pernambuco/Brazil), for the taxonomic identification of the fungus, the technical help from Ideval Azarias de Souza and the financial support of the Conselho Nacional de Desenvolvimento Científico e Tecnológico (CNPq).

\section{References}

COCHRANE, V. W. Physiology of Fungi. New York: John Wiley, 1958.524p.

HANKIN, L.; ANAGNOSTAKIS, S. L. The use of solid media for detection of enzyme production by fungi. Mycologia, 1Lawrence,v.67, p.597-607, 1975.

JABLONSKY, I. Changes in biochemical and physiological activities of substrates colonized by fungi P. ostreatus, $L$. edodes and A. aegerita. INTERNATIONAL SCIENTIFIC CONGRESS ON THE Cultivation Of Edible Fungi, 11,1981, Austrália.Procedings International Scientific Congress On The Cultivation Of Edible Fungi, Austrália, 1981, p. 659-673.

KALBERER, P. P. An investigation of the incubation phase of a shiitake (Lentinus edodes) culture. In: Elliot, T. J. (ed.). Science and Cultivation of Edible Fungi. Roterdam: Hardcover, 1995, p.375-383.

LINCOFF, G. H. National Audubon Society Field Guide to North American Mushrooms. New York: Alfred A. Knopf, 1995. 926p.

MILES, P.G.; CHANG, S. T. Mushroom Biology: Concise Basics and Current developments. Singapore: Word Scientific, 1997. 194p.

PONTECORVO, G.; ROPER, J. A.; HEMMONS, L. M.; MCDONALD, K. D.; BUFTON, A. W. The genetics of Aspergillus nidulans. Adv. Genet.,San Diego, v.5 p.141$238,1953$.

PRZYBYLOWICZ, P.; DONOGHUE, J. (1990). Shiitake Growers Handbook: The Art and Science of Mushroom Cultivation. New York: Kendall/Hunt, 1990. 217p.

SPOONER, B. Mushrooms \& Toadstools of Britain and Europe. London: Harper Collins , 1996. 255p.

TANAKA, Y.; MURATA, N.; KATO, H. Behavior of nuclei and chromosomes during ascus development in the mating between either rice-strain or weeping lovegrassstrain and ragi-strain of Pyricularia. Ann. Phytopathol. Soc. Jpn., Tokyo, v.45, p.182-191, 1979. 